\title{
British colonial politics and public health: the Rockefeller Foundation's effort to develop public health nursing in Sri Lanka
}

\author{
Soma Hewa \\ School of Policy Studies, Queen's University, Kingston, Ontario, K7L 3N6, Canada
}

Correspondence: Prof. Soma Hewa; (hewas@queensu.ca)

\begin{abstract}
This paper examines the Rockefeller Foundation's role in the development of public health nursing at the Kalutara health unit in Sri Lanka, and the difficulties it encountered due to British colonial politics on the island.
\end{abstract}

Key words: Public Health Nursing, Kalutara Health Unit, Rockefeller Foundation

\section{Introduction}

On July 1, 1926, when the first health unit in Asia was inaugurated at Kalutara-Totamune, a suburb $43 \mathrm{~km}$. south of Colombo, Sri Lanka, Dr. W.P. Jacocks of the Rockefeller Foundation stated that "[this day] will be remembered by health workers in Ceylon as the day on which a real step forward was taken in rural health work along modern lines"(1). Over the years, the Kalutara health unit grew steadily, and became Sri Lanka's premier training center of public health personnel.

The health unit program was based on the Rockefeller Foundation's experience in the "county health unit system" in the southern United States, where Jacocks had worked as a public health officer of the Rockefeller Sanitary Commission. Following the Foundation's hookworm control program on the plantations in Sri Lanka, Jacocks was appointed as the "Advisory Health Officer" to the Department of Medical and Sanitary Services. It was in this capacity that Jacocks and his Sri Lankan counterpart, Dr. S. F. Chellappah, developed the health unit system. Besides health units, Jacocks was involved in the creation of a Sanitary Engineering Division in the Department of Medical and Sanitary Services. As the health units grew steadily, Jacocks spearheaded a campaign to train public health nurses in Sri Lanka. This paper examines his effort to develop a public health nursing program at the Kalutara health unit, and the difficulties he encountered due to British colonial politics, which almost scuttled the health unit program.

\section{Training Public Health Nurses}

Since the opening of the first health unit, the Rockefeller Foundation undertook several studies to assess the need of public health personnel in Sri Lanka. In 1926, Jacocks undertook the earliest study, titled Ceylon Nursing in Government Controlled Institutions. The study reported that there were no public health nurses in the country. In the same year, Dr. W.S. Carter of the Rockefeller Foundation carried out another study, which suggested the creation of a public health nursing program (2).

Following these reports, the government established the "post of public health nurse" at the Kalutara health unit in 1926. A matron was recruited from the Colombo General Hospital with a brief training in maternal and child welfare work, and diagnosis of hookworm and malaria infections. Two more hospital matrons were recruited later, and given the same level of training at Kalutara. This approach proved to be unsatisfactory. Within a few months, two of the nurses resigned while the third one returned to hospital service. Between 1926 and 1928, 
at least 8 hospital matrons were recruited as public health nurses for the Kalutara health unit, and they all either resigned or returned to hospital jobs.

The public health nurse was a key position in the health unit program, and in 1928 there were five health units on the island without public health nurses. The government was planning to establish two more health units during 1930 in the North, and North-Central provinces. Against this background, Jacocks recommended that the government recruit a full-time Medical Officer to train public health nurses at Kalutara. He further suggested that this officer should also develop a separate maternal and child welfare unit at the Department of Medical and Sanitary Services. For the position, he recommended Dr. V. Chinnappah, a female Medical Officer from Madras (3).

In 1928, with the appointment of Chinnappah, the government began training public health nurses at the Kalutara health unit. Under the leadership of Chinnappah, seven hospital nurses were selected for training. However, in spite of having a full-time public health officer in charge of the program, it failed to retain the new recruits, highlighting the fact that the problem in the public health nursing at Kalutara was much more than the need of a full-time Medical Officer to conduct the training. As the training was not progressing as expected, the Department of Medical and Sanitary Services let Chinnappah return to India, and placed the program under Dr. Das Gupta, the Medical Officer of Health $(\mathrm{MOH})$ at the Kalutara health unit.

Miss. Mary Beard, the director of nursing of the Rockefeller Foundation, who visited the island to assess the progress of the health unit program reported: "It is the plan of the authorities to extend health units to the entire Island and is therefore of great importance to provide a growing supply of public health nurses, so that standardized personnel may be available"(4). Beard also noted that the Rockefeller Foundation's own effort to utilize the Kalutara health unit as a training facility for its programs in Asia urgently needed qualified staff: "The most encouraging feature of the Public Health program in Ceylon is the Health Unit at Kalutara....[which] has become so thoroughly incorporated into the life of the villagers that I do not believe they would ever do without it...It would therefore seem advisable to have a qualified public health nurse Supervisor for the Kalutara Unit, especially as this Health Unit is to a considerable extent attracting attention as a model for other Health Units."

The shortage of public health nurses was a major problem for the health unit program. As revealed by the Foundation's reports, several factors contributed to this initial setback. The biggest reason was the policy of selecting unmarried hospital nurses as public health nurses. When the post of public health nurse was first created in 1926, it was decided that only unmarried women with nursing backgrounds should be selected. It was believed that they would not require a long period of training, and would be free of personal responsibilities, such as family, in the beginning of their career. However, the problem was that hospital nurses preferred hospital jobs to fieldwork, and felt that the difficult work in public health nursing was not duly compensated. Beard pointed out that the "living conditions provided for pupil nurses are utterly inadequate so that this prevents a nicely brought up girl from taking the nursing course." Perhaps the most serious criticism was that these women were not trained in the principles of public health nursing, and such training could not be done in a short period: "Public health nursing requires an excellent background of character training, a disciplined mind and a sound and vigorous physique to begin with, and after that it will take some years of carefully directed education in the principles and practice of public health nursing to produce a satisfactory public health nurse".

At this juncture, the government realized that the existing policy of selecting unmarried hospital nurses was not working. In 1930, the Legislative Council appointed a committee, headed by Mr. C. W.W. Kannangara, to determine a whole range of issues, including the qualifications of the candidates, the length of training, curriculums, salaries, and specific duties of public health nurses. While the committee was making its deliberations on these issues, a number of other important changes took place in the Department of Medical and Sanitary Services that helped to re-focus the attention on the health unit programme.

Naturally, one would think that experienced public health officers, like Jacocks and Chellappah, who had been involved in the health unit program right from the beginning, could not be oblivious to the 
shortcomings of the public health nursing program when they decided to start training at Kalutara. The question is, why did they decide to go ahead with training in such a situation? Two important factors seem to have forced the decision to begin premature training of public health nurses.

First, the importance of the health unit program in general, and the Kalutara health unit in particular, for the Rockefeller Foundation's public health project in the East must be understood. The health unit program was regarded as a "model" to be expanded in the region. A number of internal memorandums highlighted this importance: "Experience has confirmed the wisdom of having the first health units in the East started in Ceylon. Owing to its central location, Ceylon has served as a convenient training ground and demonstration center for health officers from Burma, Madras, Mysore, Travancore, the United Provinces, Federated Malay States, Java, and Sumatra, and visitors from many countries have seen the work...Most of this training has been given by the Kalutara unit"(5). Given the importance of the Kalutara health unit in the East, Jacocks wanted to have a fully functioning health unit. He argued that if "the Health Unit fails to succeed and develop in Ceylon, it will be for lack of public health nurses." If the Kalutara health unit were to function as the "model" for public health programs in the region, such a failure would amount to a major setback for the foundation's image. Against this background, Jacocks must have felt that he should do whatever necessary to address the need of public health nurses, even if it meant a short-term solution. For him, failure was not an option.

Second, it was also possible that Jacocks may have been particularly sensitive to colonial politics given his experience in the hookworm control campaign on the plantations, where planters and the government could not agree on the responsibility of providing latrines for the Indian immigrant laborers. That particular dispute contributed to the failure of the project on the estates. The health unit program in Sri Lanka was essentially a "brainchild" of Jacocks. Although he had the support of most Sri Lankan Medical Officers, such as Chellappah, who was a former fellow of the Rockefeller Foundation, and Dr. S.T. Gunasekera, a Senior Medical Officer of the Department of Medical and Sanitary Services, they were not the most influential people in the
Department. In fact, the most powerful person, Dr. J.F.E. Bridger, the Director of the Department, refused to cooperate with Jacocks. He informed New York office that "Health unit work continues to be popular with all except a few disgruntled Medical Officers of health and government Medical Officers and a few politicians". In particular, Jacocks mentioned the lack of support he was getting from Bridger, whom he described as "intensely interested in politics."

Jacocks specifically referred to an ongoing acrimony between Bridger and Gunasekera, which he "feared" could undermine the public health work in Sri Lanka: "Much to my regret," wrote Jacocks, "I can see no change in the relationships of Dr. Bridger and Dr. Gunasekera, and as the latter is by reason of his position a vital factor in all local public health measures, the outlook is not too rosy for that harmonious spirit which is necessary to get the best results with the least lost motion...At the moment, this relationship seems to me to be the outstanding difficulty in the advancement of public health here". Although Jacocks referred to Gunasekera's "position" as a "vital factor in all local public health work", it was, nevertheless, Bridger who had the authority as the director of the Department. Jacocks went on to point out that, "In developing the work in here I have endeavored, and I think successfully, to keep it in Ceylonese...hands, so that at present a local man is thoroughly conversant with, or is being trained in all phases of work which have been undertaken under our inspiration" (6). This certainly indicates that Jacocks preferred to have a "local man" at the helm of the public health campaign, and the most senior "local man" in the Ceylon Medical Service at that time was none other than Gunasekera.

Although the exact reason for this animosity is impossible to pinpoint, Gunasekera, given his highprofile status in the Medical Service, may have expected to become the Director of the Department in 1925, and again in 1930. As we know, in both occasions, it was not to be. There is evidence, however, that when Gunasekera finally became the director in 1936, some members of the Colonial Office raised objections to his appointment on the grounds that "if a Sinhalese were chosen it would upset the Tamil and Burgher [mixed descendants] Medical Officers". The duplicity of such assertions by the Colonial Office's mandarins becomes 
transparent as they continued to question "the suitability of an indigenous candidate" for the high post when Chellappah [a Sri Lankan Tamil] succeeded Gunasekera as the Director of the Department in 1942 (7). The colonial administration wanted to keep the senior positions in the hands of the British. Against these difficult circumstances, Jacocks did his best to ensure that the health unit program would not end up in the same predicament as the hookworm control campaign on the plantations (8).

In the later part of 1929, Jacocks learned that Dr. R. Briercliffe, the Assistant Director of Health Services in Palestine, would become the new Director of the Department of Medical and Sanitary Services in Sri Lanka. Hoping to change the prevailing atmosphere in the Department, and to give a better understanding of the Foundation's role in public health on the island, Jacocks arranged through the Rockefeller Foundation an invitation to Briercliffe to visit the United States as a "guest" of the Foundation. In a memorandum to scientific directors of the Foundation in 1929, Dr. Victor Heiser, the coordinator of the Foundation's Eastern operations, stated that, "Briercliffe is an exceptionally competent administrator who for some years has been the Assistant Director of Health for Palestine, and to him is due much of the excellent administration of Palestine health service. When the position of the Director of Medical and Sanitary Services for Ceylon becomes vacant, Briercliffe will be seriously considered by the Colonial Office for this post..."(9). Although this was not an unusual practice, the Foundation's invitation to Briercliffe had a special significance as it took place against the hostile atmosphere in the Department of Medical and Sanitary Services that threatened the health unit program. It must be seen as a diplomatic move on the part of Jacocks (10).

As expected, Briercliffe became the Director of the Department of Medical and Sanitary Services in 1930. Soon after, he visited the United States to learn about county health organizations and was very impressed. As in the health unit program, Briercliffe noted, the county health organizations focused on improving sanitary conditions, preventing communicable disease, providing maternal and child welfare services, health education, and collecting vital statistics. With regard to the role of public health nurses, Briercliffe observed that the "nurses are a great factor in spreading health education, they deal with communicable diseases including tuberculosis, child welfare, and through cooperation with school the education authorities, school medical work". He found that the public health nurse was the key to deal with "all aspects of public health issues" in a community (11).

The study tour had a powerful impact on Briercliffe. Upon his return, he wrote that the trip was "an immense profit to the work" he would be undertaking in Sri Lanka. He took prompt action to address the ongoing shortage of public health nurses in health units. Briercliffe decided to recruit married women, who had been trained in hospital nursing, but had "resigned from the service on account of marriage" (12). He decided to re-train them in midwifery, and in public health nursing for a period of one year before employing them in the health units.

Briercliffe initiated several public health projects, including "village and town sanitations", aimed at providing public and private latrines, a typhoid control program, water supply schemes in health unit areas, and the maternal and child welfare programs (13). Unlike his predecessor, Briercliffe was pragmatic and an avid supporter of the health unit work, which made it all the more easier for Jacocks to become actively involved in the health unit program in Sri Lanka. In his year-end report to the Foundation in 1930, Jacocks praised Briercliffe, and described his relationship with the Department as "most cordial".

\section{Report on Public Health Nursing}

In 1931, the Executive Committee of Health of the Legislative Council submitted its report on public health nursing. It made several recommendations to meet the requirements of the health unit program. The Committee praised Briercliffe's decision to recruit married women as an interim solution to the shortage of public health nurses in health units. It underscored the difficulty of attracting educated women for public health nursing at the level of salary the government was willing to offer (14).

The Committee pointed out that the type of candidates suitable for public health nursing were "young and educated women who were well versed 
in their native languages", and it was this class of women "who has supplied successful teachers" for the country's schools. However, women of this class would not join public health nursing at the current level of payment. Therefore, it recommended creating a "junior grade of female health workers".

The required qualifications for the junior "health workers" were however ambiguous. The Committee simply stated that "the type of female Health Worker that is considered suitable viz., a woman of school teacher class". The qualification to be a school teacher during that time was the Junior School Leaving Certificate, and the proposed junior health worker would earn more or less the same salary as the schoolteacher, but considerably less than a public health nurse.

During the first six months they were to undergo training in midwifery at the Lady Havelock Lyingin-Hospital in Colombo, followed by 12 months training in public health nursing at Kalutara health unit and the local hospitals. The training focused mainly on maternal and child welfare work, antenatal and postnatal practices, nutrition and feeding, vaccination against infectious disease, administering treatment for hookworm infection and malaria, conducting health education seminars for school children and collecting vital statistics. Every three years, they would undergo a "refresher" course at Kalutara.

Although the proposed post of "junior health worker" was not exactly the solution that Jacocks had wanted, given the difficult financial circumstances he expressed satisfaction with the government's response. He argued that "this will not prove a disadvantage as opportunity will thus be given to consolidate the present situation and plan on sound lines for the future" (15).

\section{Conclusion}

The Rockefeller Foundation played a pivotal role in the development of public health in Sri Lanka in the early twentieth century. It's effort, however, encountered numerous obstacles. The Foundation's representatives criticized the colonial administration for its reluctance to recruit local personnel for senior positions in the health services. For these reasons, the British colonial administrators loathed the American involvement on the island.
Dr. Jacocks, who coordinated the Foundation's public health programs in Sri Lanka for almost two decades, worked closely with the Sri Lankan counterparts to develop essential health services, and to train local public health personnel for the health unit program. It was largely due to Jacock' expertise and diplomatic skills that the health unit program succeeded in Sri Lanka.

\section{References}

1. Rockefeller Archive Center (RAC), First Annual Report of the Health Unit Kalutara Badda, p.1, 1926. Record Group (RG). 5, Series (Se). 3, Box 198.

2. RAC, Public Health Nursing in Ceylon, W. S. Carter, 1926. RG. 1.1, Se. 462.

3. RAC, Letter from Jacocks to Heiser, Nov. 28, 1927. RG. 1.1, Se. 462, Box 1.

4. RAC, Note on Public Health Nursing in Ceylon, Mary Beard, 1932. RG. 1, Se. 462, Box1.

5. RAC, Ceylon, Kalutara Health Unit Designation for Two Years, pp. 33322-3, 1933. RG. 1.1, Se. 462, Box 1.

6. RAC, Letter from Jacocks to Heiser, Nov. 28, 1927. RG. 1.1, Se. 462, Box 1.

7. Margaret Jones. Infant and Maternal Health Services in Ceylon, 1900-1948: Imperialism or Welfare?. Social History of Medicine 2002; 15(2): 263-89.

8. Soma Hewa. 1995 Colonialism, Tropical Disease and Imperial Medicine: Rockefeller Philanthropy in Sri Lanka, University Press of America, Inc. Lanham, Maryland.

9. RAC, Memorandum by Dr Heiser, re: Inviting Dr. R. Briercliffe, Assistant Director of Health in Palestine, as a Guest of the I.H.D., July 1, 1929. RG. 1.1, Se. 462, Box 1.

10. RAC, Invitation to Briercliffe from Heiser, July 2, 1929. RG. 1.1, Se. 462, Box 1.

11. RAC, Review of a Visit to the United States under the auspices of the Rockefeller Foundation, September 2 to 24, 1932, by Dr. R. Briercliffe, Director of Medical \& Sanitary Services of Ceylon, pp. 1-8. 1932. RG. 1.1, Se 462, Box 1.

12. RAC, Public Health Nursing in Ceylon, p. 4. 1931. RG. 462, Se. 5, Box 48.

13. Soma Hewa. Rockefeller Foundation's Typhoid Control Campaign at Kalutara-Totamune in Sri Lanka”, Galle Medical Journal 2011; 16(1): 29-32.

14. RAC, Report of the Committee on the recruitment of Public Health Nurses, p.7, 1931. RG 462, Se. 5, Box 48.

15. RAC, Ceylon, Annual Report for 1930, p. 3. 1930. RG. 5, Se. 3, Box 198. 